\title{
ANALYSIS OF HUMAN RESOURCES MANAGEMENT IN THE NEW NORMAL ERA TO DEVELOP LEARNING STRATEGIES
}

\author{
Finny Redjeki \\ Universitas Sangga Buana, Bandung \\ Email: finnyredjeki@usbypkp.ac.id
}

\begin{abstract}
The sudden emergence of the Covid-19 virus has caused changes in various aspects of our lives. These changes then lead to a new rule that needs to be followed by everyone, so this situation is referred to as the new normal. Human resource management has a vital role in life in the new normal and oversees various associations or institutions. In dealing with the new normal, various learning activities need to be changed so that the spread of the Covid-19 virus can be stopped or inhibited. Human resource management that oversees educational institutions needs to find new learning strategies. This research was carried out using a qualitative approach with secondary data sources. The study results indicate that the implementation of virtual learning guided by the teacher needs to be carried out with careful efforts, preparation, and debriefing to reduce errors that occur. Then, on the other hand, parents need to help and supervise their children in learning so that there is no laziness or cheating during exams at home. Through the role of teachers and parents, the value in the academic world can be upheld, so this strategy is considered appropriate in this new normal era.
\end{abstract}

Keywords: Human Resource Management (HRM), New Normal, Learning Strategy.

\section{A. INTRODUCTION}

Consciously, we know that human resource management is a core part of an association or an educational institution. Not to be missed in this, how the human resources themselves dedicate themselves to welcoming the transition from normal (as usual) to a pandemic (because it has hit dozens of countries in the world) to become a new normal (normal with new habits) (Levrini et al., 2021). Why was the new normal era chosen instead of the original normal? Because at this time, we have been required to be ready, after several months of refraining, like the process of fasting from leaving the house for things that are not needed (Dziuban et al., 2018). Even some people are required to remain silent for an undetermined time as a form of endeavor for the pandemic that may befall those who are not picky/know anyone (Zulkarnain $\&$ Restiana, 2021). For almost three months, government agencies, education, and elements that require too much physical contact have to be temporarily suspended from following the rules of social distancing to prevent this fast-growing virus from spreading (Shah et al., 2021). Regarding the world of education, where children have longer holidays than usual, even based on the glasses that are seen now, boredom and boredom begin to decorate themselves as excuses for missing teachers, peers, lessons at school, and activities that they usually do (Tong et al., 2020). Indeed, educational institutions also follow a fast-paced flow to continue to carry out learning that is functioned by the online method (Peimani \& Kamalipour, 2021).

Learning strategies referring to the new normal era are guided by following health protocols and triggering teachers as part of the most important human resources in teaching and learning activities to have precise moves to manage learning without face-to-face without eliminating the learning essence (Dwivedi et al., 2020). As currently circulating on social media, teachers often give examples and then share links and ask students to follow them at home, which is an efficient way to learn amid a pandemic with the new normal era (DonitsaSchmidt \& Ramot, 2020). 
However, the ineffectiveness of both human resources, in this case, educators, students, and parents, found various obstacles with the virtual method applied to this new civilization of human life. Therefore, HR must be familiar with its power to improve by innovating with new strategies to smooth KBM with the era that is currently being lived (Toh \& Kirschner, 2020). Experts have also researched long ago so that their findings are as follows stated by Ni'mah that there are also obstacles from this E-learning, namely:

1. The electricity can go out while accessing the learning program

2. Poor internet network

3. Uncertain commitment from parents

4. Students who have difficulty learning this way

5. Misunderstanding between lecturers/teachers and students/students

6. Ignorance of science and technology (Mardliyyah, 2020)

Therefore, the researcher then intends to research the analysis of resource management in the new normal era to develop good learning strategies.

\section{B. LITERATURE REVIEW}

\section{Human Resource Management}

Human resources (HR) is a crucial capital an organization owns because it has intellectual competence. The quality and capability of human resources (HR) play a significant role in an organization's progress (Abdeldayem \& Aldulaimi, 2020). Human Resource Management (HRM) is how to utilize individuals to achieve the goals that the organization has set. Good HR management will affect how successful each company or organization is (Gilal et al., 2019). The purpose of HR management is to achieve the maximum contribution of each person in the organization and manage these people in a certain way. Existing human resources must develop their potential to the maximum extent possible to contribute to the achievement of company or organization goals effectively and efficiently (Carnevale \& Hatak, 2020).

The term HR management itself essentially consists of "management" and "human resources". Management means art and a process of utilizing existing resources effectively and efficiently to achieve specific goals (Razak et al., 2018). Human resource management is a science that is also an art of allocating various workforces that are owned to maximize their potential to help companies or organizations realize their goals and ideals (Mousa \& Othman, 2020).

Human resource management itself plays a vital function in the organization and other functions such as production, finance, and marketing (Yu et al., 2020). Today, various studies have shown that the HR function plays a critical role in the organization, even as a source of competitive advantage (Abbasi et al., 2021). Environmental changes in current business models have also significantly impacted companies and organizations. HR is now undergoing a significant change that is no longer only partial but leads to a strategic and integrated sector (Davidescu et al., 2020).

HR management uses systems and practices that aim to maximize the company's performance. This is because the course of human resource management is a source of increasing company efficiency (Source of Efficiency) and also a source of value creation for the company (Source of Value Creation) (Bombiak \& Marciniuk-Kluska, 2018). Implementing human resource management practices within an organization or company will be a competitive advantage that is difficult to imitate by competitors or purchased freely in the market (Hamadamin \& Atan, 2019).

Today, it is known that more and more companies have poor performance due to poor management or ineffective and efficient human resource management. This is, of course, the leading cause of the unskilled workforce, uncompetitiveness of the organization, declining performance, and low levels of productivity. Okoye and Ezejiofor said that organizations and 
business are very uncertain, so it is necessary to increase understanding about increasing employee contributions to organizational productivity and company profits (Sharif, 2021).

\section{New Normal}

WHO International has declared Covid-19 as pandemic disease. The current situation certainly directly impacts the political, economic, social, and cultural aspects, as well as parts of community welfare (Dubey et al., 2020). At this time, we certainly need strategies and real efforts to accelerate the handling of life by adapting to a new life.

The term "new normal" is a term for changes in humans' attitudes and behavior in daily activities and activities, both in lifestyle and work patterns which are no longer the same as before (de Haas et al., 2020). The purpose of this "new normal" is so that human life can continue, of course, productively and safely from fear of the Covid-19 virus. This new normal is applied in work, study, and daily activities (Joshi \& Gupta, 2021).

On the basis of efforts to prevent the spread of Covid-19 transmission in Indonesia, the Government, through Presidential Decree No. 11 of 2020, finally stipulates an emergency condition due to Corona Virus Disease 2019 (COVID-19) in Indonesia following the provisions of the Ministry of Health of the Republic of Indonesia Number HK.01.07/MENKES/328/2020 concerning Guidelines for Prevention and Control of Corona Virus Disease 2019 (COVID-19) in Places Office and Industrial Work in Supporting Business Continuity in a Pandemic Situation (Santoso \& Singadimedja, 2021).

\section{METHOD}

The study used secondary data as the primary material for research data. The data used comes from various reports and previous studies that are still relevant to this research. A qualitative approach will be used as an analytical method in this research.

\section{RESULT AND DISCUSSION}

\section{Towards the New Normal Transition}

In this new, unprecedented reality, post-Covid 19, the world is shocked by the term new normal, which makes people's lives restructure until eventually, leading to debate and discussion about the new normal. The word "new normal", which means normality or new normal, has been around for a long and is not foreign. The Government's steps to implement the new normal are very appropriate. As for the madrasa and school community, it is essential to pay attention to these steps towards the successful implementation of the new normal by paying attention to procedures.

Various terms are used to understand the word, such as a new life order, adaptation to new habits, transitions to welcome a new normal, and adjustments to life patterns. In its official Instagram account, the Ministry of Education and Culture (Kemendikbud) explained that the word new normal is a new normal that has never existed before. According to a government spokesman in accelerating the handling of COVID 19, the new normal is interpreted as a new life movement, a productive and safe life from the coronavirus outbreak. It is possible that we may not return to the situation as before (the old normal); therefore, we must change.

The substance of the new normal should not be considered limited to easing PSBB and public transportation. Although many were surprised, it was finally understood as something normal and should work. According to Paul Glover's opinion in the Philadelphia City Paper 2009 that in explaining a condition that was initially considered unusual to be something that is then regarded as normal, reasonable, and finally widely accepted, the new normal that is accepted by the community becomes something which is then understood as a normal condition. These various changes that continue to occur create conditions known as "the new 
normal". The new normal has multiple responses from the public. This is natural, as long as it is intended for a better life and is carried out based on valid research studies.

WHO has set several barometers before the Government implements the new normal, including ensuring controlled transmission, the health system is in good condition, guaranteeing preventive measures in the work environment, preventing imported cases of covid, and providing public awareness and participation. In line with that, the Government has determined three standards for reducing PSBB by looking at transmission based on the reproduction rate (R0), the level of health system capacity in responding to Covid-19 services, and the level of mass Covid-19 tests carried out.

Seeing and observing the standards and barometric above, it can be said that the new normal movement cannot be implemented as a whole if the health parameters have not been met. This is due to the accuracy or authenticity of the COVID-19 data, making it difficult to calculate the reproduction rate (RO). Jusuf Kalla predicts that the new normal will last for at least 3 (three) years if a covid 19 vaccine is found in February 2021, and the following is mass production of vaccines in August and September 2021 (Mietzner, 2020). Many countries have decided to return to a new life movement (new normal), such as China and South Korea, however, they still follow health protocols. But eventually, the country re-imposed social restrictions.

The phenomenon above agrees with the statement that is often conveyed by University of Indonesia epidemiologist Pandu Riono: "If you continue to force the implementation of the new normal phase, while the requirements and criteria that have been determined have not been met, then be prepared to bear the increase in cases" (Chen et al., 2020). The author believes that before re-establishing a new life movement (new normal), it is better to precede the transition stage, which is a stage that will determine the success or failure of the new normal stage later.

There are two stages of change that can be applied: the first stage: the termination stage, then the second stage, the transition stage, which is a procedure in which one leaves old habits and enters new habits or begins with a break and ends with a beginning.

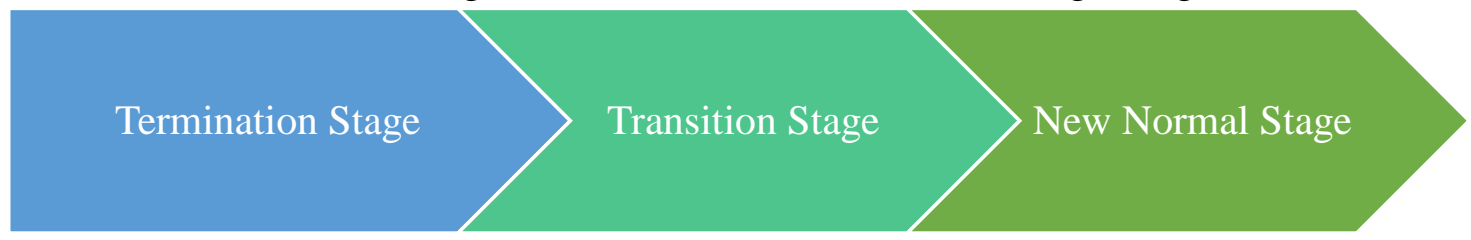

Figures 1. 3 Stages Towards New Normal

The author sees that most have not made it through the first phase. People are not disciplined in following health protocols. It becomes difficult to enter the subsequent phases, namely the transition phase, let alone the new normal phase. Suppose the transition stage fails to implement changes. In that case, it will likely fall into the abyss of destruction and it isn't easy to get back up to the new normal stage. In contrast, if it succeeds in undergoing the transition stage, it is not absurd that there will be a very significant increase to the new normal stage. Therefore, the author views the importance of preparing and managing the transition phase as productively and effectively as possible before undergoing the new normal, as WHO and the Government have approved indicators.

\section{Learning Strategies in the New Normal Transition}

Controversy among the Indonesian people about the opening of schools during the transition to the new normal is becoming increasingly resonant and very dilemmatic. Of course, this has its arguments. One of the reasons people are pro-school opening is that the school's treasury is running low so that it requires income to pay teachers, especially private schools. While those who mainly protested came from the parents/guardians of students. They are afraid 
because even though they have entered the new normal transition, Covid-19 cases have not entirely stopped. Even if you see positive cases are increasing because of the extraordinary testing and tracing by the Government. Imitating England, Germany, and Vietnam, these three countries have decided to return to the New Normal and open schools. Still, they follow rigorous health protocols, such as school hallways are only used in one direction, must wear masks, Students in classrooms are limited, teaching time is divided into two waves, the distance between students' seats is 1.5 to 2 meters apart. Windows are kept open for air circulation.

If the school year is postponed or postponed, there will be several impacts and adjustments so that the school year will continue to be carried out according to its normal time with online-based learning patterns or not face-to-face learning".

In the internet era, countries around the world have made various effective efforts in online education, but online education is more of a complement to school education, and largescale normal online education does not have many cases. Therefore, the Government needs to close schools and carry out online learning. The "School Out, But Class's on" campaign launched by the Chinese Government during the COVID-19 epidemic created a normal largescale online education application.

On June 15, 2020, the Ministry of Education and Culture, the Ministry of Religion, the Ministry of Health, and the Ministry of Home Affairs decided to compile guidelines for the implementation of learning in the academic year and the new academic year during the COVID 19 period. Principles of Education Policy in the COVID-19 Pandemic Period with the principles a policy that the health and safety of students, educators, education staff, families, and communities is a top priority in setting learning policies. The pattern of learning patterns for early childhood education, basic education and secondary education, namely the new 2020/2021 teachings, will continue to start in July 2020, for areas in the yellow, orange, and red zones, it is prohibited to conduct face-to-face learning in education units, education units in these zones continue to learn from home. Normal in the education sector is very different from other sectors of life, so it must be fully alert and careful.

Based on the situation, general emergency management is the best solution. An emergency policy initiative called "Suspending Classes Without Stopping Learning" aims to turn teaching activities into online teaching. Distance or online learning has become the norm. Online learning is very much needed to balance the development of the world of education which is supported by information technology that leads to the digital era, both process and content in the era of the industrial revolution 4.0. With online learning, the learning process can occur anywhere and anytime flexibly.

Education in this emergency period needs to be distinguished from the normal period. The meaning of "Closing classes without stopping learning" reflects learning in a broad sense, which not only refers to structured learning from the school curriculum, but also includes learning various content. Such learning can be carried out in various ways, the purpose of which is to support student growth. Meanwhile, it was emphasized that knowledge of epidemic prevention and control needs to be included in addition to the formal national curriculum, with particular emphasis on popularizing epidemic prevention knowledge, expressed through life education classes, public safety education and mental health education.

Public safety education through policy implementation is very important to pay attention to starting from a dynamic process, emergency management system to linking the objectives of all steps, it is appropriate for schools, (principals, teachers and parents) to collaborate to implement a public emergency management system, which is a procedure which allows for centralized emergency decision making and circulation of information, and a system for classroom management and multi-level response. 


\section{Human Resource Management (HR) in Improving Learning Strategies in the New Normal Transition Era}

Several schools in Indonesia are closed to prevent the spread of COVID 19, so the parties who are most disadvantaged are the entire academic community, if schools are closed. However, if observed accurately, students are the ones who feel the most impact. The problem is, if learning stops or is postponed, the time for carrying out learning activities for a year will be delayed until an unspecified time limit. Therefore, education that is oriented towards global relevant needs is needed, namely relevant needs.

For this reason, education requires reliable resources, both human resources and infrastructure for educational efficiency. The existence of Covid-19 has encouraged teachers and school academic staff to take a number of policies related to learning activities. As a person who is involved in the world of education, in fact, the author sees the impact of the study at home policy for students who started from the beginning of entering the country with Covid19. The scheduled agenda has become a mess, so like it or not, educational institutions must also evaluate policies to anticipate the impact of Covid-19. The abolition of the National Examination, then the final school exam which must be held via WhatsApp is one of the changes faced. The management of educational institutions must be able to adapt to this pandemic and are required to continue to carry out the scheduled routine agenda while maintaining social and psychological distancing.

When learning in educational institutions stops due to this epidemic, public opinion towards educational institutions, especially teachers, will become increasingly positive. In relation to professional competence, the teacher must master, among others:

a. Materials, structures, concepts, and scientific mindsets that support the lessons being taught.

b. Understand competency standards and basic competencies of the subjects/development areas being taught.

c. Elaborating creatively taught learning materials.

d. Growing professionalism in a sustainable manner by taking introspective actions.

e. Able to use ICT to communicate and develop themselves.

It has been mentioned many times above that it is necessary to have structured collaboration and management, be it teachers, principals and parents, to be able to present online learning. The principal with such a strategic position must be able to display effective leadership, good school management must be accompanied by good teachers, so that the curriculum can be translated into good learning. The effectiveness of a school in achieving its vision, carrying out its mission, meeting goals and targets, and in carrying out learning activities requires the existence of a principal who displays effective leadership.

The forms of school management that can be applied in the new normal era include:

a. Teacher

1) Coordinate with school principals and review curriculum

2) Learning profile, status and needs during the pandemic, as well as family support

3) Teacher self-assessment, teacher support, teacher resources, structuring learning, support and feedback to students and assessment

b. Parent

1) Controlling student learning

2) Maximizing communication with the teacher goes well

3) Planning comprehensive learning both schedules and assignments, according to the conditions of parents and students

4) Coordinate with teachers regarding study assignments 


\section{E. CONCLUSION}

Human resource management in improving learning strategies in the new normal era is through efforts, mature readiness, debriefing both in terms of ICT skills and the habit of taking virtual learning. Maybe the pandemic was the beginning of the rise or the stipulation of online learning rules for students in Indonesia by the Government and the Ministry of Education and Culture itself, even though previously elite, bona fide schools had already set foot in learning by utilizing technology, but certainly not as dominant as before the pandemic occurred. For this reason, 2 main elements of teaching and learning activities take place, students and teachers must be equipped, qualified and know the direction of learning that is filtered in order to minimize misunderstandings between teachers and students. Meanwhile, students, at home, study with the help and supervision of their parents so that there is no trickery, laziness and cheating during the exam. So that ethics, values / norms are still upheld in the academic world. This is the most appropriate learning strategy in this new normal era. The changing times are so fast, ready or not, all regions must follow if they don't want to be left behind. There are big changes and challenges faced by continuing to carry out activities in the midst of a pandemic, but this is a solution. From here, students can learn from the pandemic situation, and stay motivated and guided by teachers to be successful in the future.

\section{REFERENCES}

Abbasi, S. G., Shabbir, M. S., Abbas, M., \& Tahir, M. S. (2021). HPWS and knowledge sharing behavior: The role of psychological empowerment and organizational identification in public sector banks. Journal of Public Affairs, 21(3), e2512.

Abdeldayem, M. M., \& Aldulaimi, S. H. (2020). Trends and opportunities of artificial intelligence in human resource management: Aspirations for public sector in Bahrain. International Journal of Scientific and Technology Research, 9(1), 38673871.

Bombiak, E., \& Marciniuk-Kluska, A. (2018). Green human resource management as a tool for the sustainable development of enterprises: Polish young company experience. Sustainability, 10(6), 1739.

Carnevale, J. B., \& Hatak, I. (2020). Employee adjustment and well-being in the era of COVID19: Implications for human resource management. Journal of Business Research, 116, 183-187.

Chen, Z., Mauricio, A., Li, W., \& Gryllias, K. (2020). A deep learning method for bearing fault diagnosis based on cyclic spectral coherence and convolutional neural networks. Mechanical Systems and Signal Processing, 140, 106683.

Davidescu, A. A., Apostu, S. A., Paul, A., \& Casuneanu, I. (2020). Work flexibility, job satisfaction, and job performance among Romanian employees-Implications for sustainable human resource management. Sustainability, 12(15), 6086.

de Haas, M., Faber, R., \& Hamersma, M. (2020). How COVID-19 and the Dutch 'intelligent lockdown'change activities, work and travel behaviour: Evidence from longitudinal data in the Netherlands. Transportation Research Interdisciplinary Perspectives, 6 , 100150 .

Donitsa-Schmidt, S., \& Ramot, R. (2020). Opportunities and challenges: teacher education in Israel in the Covid-19 pandemic. Journal of Education for Teaching, 46(4), 586-595.

Dubey, S., Biswas, P., Ghosh, R., Chatterjee, S., Dubey, M. J., Chatterjee, S., ... \& Lavie, C. J. (2020). Psychosocial impact of COVID-19. Diabetes \& Metabolic Syndrome: Clinical Research \& Reviews, 14(5), 779-788.

Dwivedi, Y. K., Hughes, D. L., Coombs, C., Constantiou, I., Duan, Y., Edwards, J. S., ... \& Upadhyay, N. (2020). Impact of COVID-19 pandemic on information management 
research and practice: Transforming education, work and life. International Journal of Information Management, 55, 102211.

Dziuban, C., Graham, C. R., Moskal, P. D., Norberg, A., \& Sicilia, N. (2018). Blended learning: the new normal and emerging technologies. International journal of educational technology in Higher education, 15(1), 1-16.

Hamadamin, H. H., \& Atan, T. (2019). The impact of strategic human resource management practices on competitive advantage sustainability: The mediation of human capital development and employee commitment. Sustainability, 11(20), 5782.

Joshi, V. A., \& Gupta, I. (2021). Assessing the impact of the Covid-19 pandemic on hospitality and tourism education in India and preparing for the new normal. Worldwide Hospitality and Tourism Themes.

Levrini, O., Fantini, P., Barelli, E., Branchetti, L., Satanassi, S., \& Tasquier, G. (2021). The present shock and time re-appropriation in the pandemic era. Science \& education, 30(1), 1-31.

Mardliyyah, A. (2020). The Implementation of Arabic E-Learning through Arabic-Online. net. LISANIA: Journal of Arabic Education and Literature, 4(1), 37-48.

Mietzner, M. (2020). Economic Capacity, Regime Type, or Policy Decisions?. Taiwan Journal of Democracy, 16(2), 1-29.

Mousa, S. K., \& Othman, M. (2020). The impact of green human resource management practices on sustainable performance in healthcare organisations: A conceptual framework. Journal of Cleaner Production, 243, 118595.

Razak, A., Sarpan, S., \& Ramlan, R. (2018). Effect of leadership style, motivation and work discipline on employee performance in PT. ABC Makassar. International Review of Management and Marketing, 8(6), 67.

Santoso, I. B., \& Singadimedja, H. N. (2021). Study On Government Policy In Managing The Corona Disease Virus Pandemi 2019 (Covid-19) In Indonesia. LEGAL BRIEF, 11(1), 211-218.

Shah, A. M., Naqvi, R. A., \& Jeong, O. R. (2021). Detecting Topic and Sentiment Trends in Physician Rating Websites: Analysis of Online Reviews Using 3-Wave Datasets. International Journal of Environmental Research and Public Health, 18(9), 4743.

Sharif, Z. F. (2021). The role of Entrepreneurial Orientation in achieving Organizational prosperity an analytical study of a sample of administrative leaders in private universities in the Kurdistan region. Review of International Geographical Education Online, 11(10), 1515-1538.

Toh, W., \& Kirschner, D. (2020). Self-directed learning in video games, affordances and pedagogical implications for teaching and learning. Computers \& Education, 154, 103912.

Tong, Y., Wu, M. Y., Pearce, P. L., Zhai, J., \& Shen, H. (2020). Children and structured holiday camping: Processes and perceived outcomes. Tourism Management Perspectives, 35 , 100706.

Yu, W., Chavez, R., Feng, M., Wong, C. Y., \& Fynes, B. (2020). Green human resource management and environmental cooperation: An ability-motivation-opportunity and contingency perspective. International Journal of Production Economics, 219, 224235.

Zulkarnain, A., \& Restiana, R. (2021). Study Of Hr Management for a Development in Learning Strategies In The New Normal Era. Devotion: Journal of Community Service, 3(2), 128-143. 